\title{
Saving Flows In The Current Expansion
}

T

AKE-HOME PAY of individuals rose substantially during 1968, but the rate of increase was sharply reduced after July by the 10 per cent surtax. Individuals continued to increase their expenditures for goods and services as they observed the parchasing power of their funds being eroded by price increases. They decreased the proportion of disposable income (income after taxes) saved, and the rate of accumulation of deposit-type savings slowed somewhat from the relatively rapid pace of 1967. Nevertheless, the rate of accumulation of deposit-type savings remained well above the pace of the 1966 "credit crunch" period.

\section{Risho rncome and proes}

Reflecting the strong growth in total demand and production throughout the year, personal income grew 9.6 per cent from November 1967 to November 1968, faster than in any one of the previous fifteen years. However, higher taxes and rising prices cancelled much of the gain to households. In the first half of 1968 disposable income grew at a 10 per cent rate, about the same as the growth of total personal income. Imposition of the 10 per cent surcharge on personal income taxes in July reduced the growth of disposable income in the third quarter to a 4.4 per cent rate, even though growth in personal income continued at nearly its previous pace.

Rapidly rising consumer prices, a response to strong demands emanating from all sectors of the economy, eroded over half of the gains in disposable income during the past year. Consumer prices rose 4.8 per cent from November 1967 to November 1968 , while disposable income increased about 8 per cent during the same period. By comparison, consumer prices rose at less than a 2 per cent average anmual rate in the decade from 1957 to 1967, eroding about one-third of the almost 6 per cent average rate of increase of disposable income during that period.

\section{Alocation of Pereonal moome}

Income taxes have been absorbing an increasing portion of total personal income since 1957 because of the progressive nature of our tax system. In 1957 individuals paid an average of about 12 per cent of their income to the Federal Govermment in the form of personal income taxes. In the subsequent ten years, personal income grew at a 6 per cent annual rate, while personal income taxes grew at a 6.8 per cent rate. Consequently, individuals paid an average of over 13 per cent of their income in Federal personal taxes in 1967. While personal income is estimated to have increased about 9.6 per cent in 1968, income tax liability of individuals is estimated to have increased 10 per cent, partly due to the surtax. As a result, about 14 per cent of income is estimated to have been paid in income taxes in 1968 .

Individuals allocated an increasing proportion of their disposable income to personal saving during the decade prior to $1968 .{ }^{1}$ Saving increased at almost a 7 per cent annual rate from 1957 to 1967, about 1 percentage point faster than the growth of personal income during the same period.

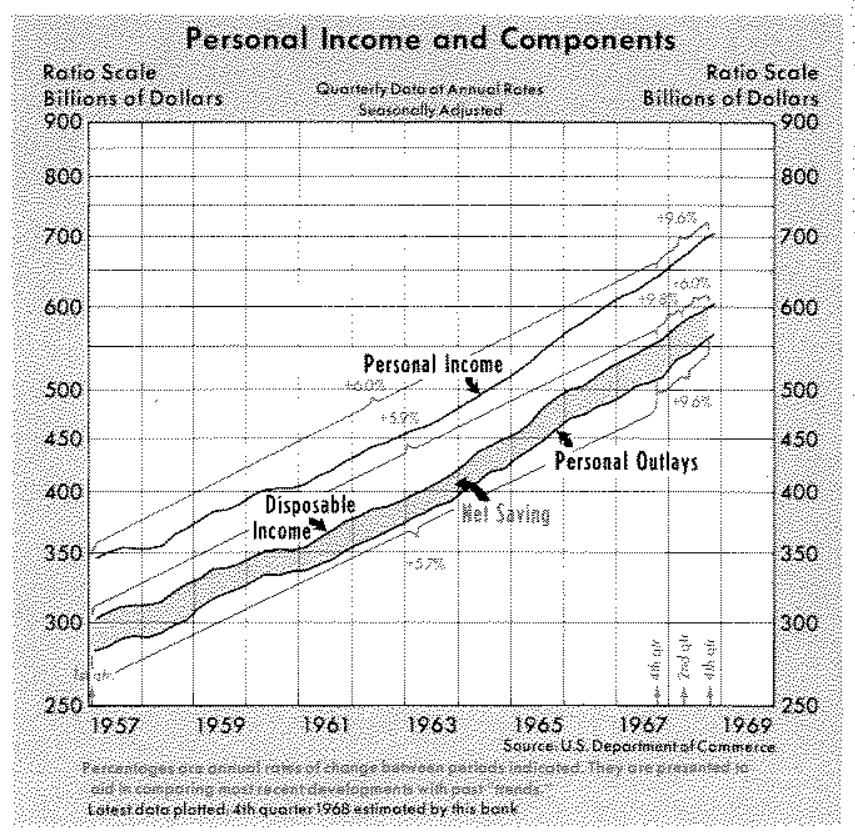

In the first half of 1968 saving incrensed at about the same rate as disposable income. In the second half of the year, after the 10 per cent surtax became

In this discussion personal saving is defined the same as by the Deparment of Commerce: disposable income minus: personal consumption expendutares (inclading durable goods, interest paid by consumers, and pessonal transfer payments to foreigners. 
effective, individuals reduced their saving rate. By reducing the share of income allocated to savings, households were able to maintam a relatively high rate of expenditures on consumption goods and services, even though the growth in take home pay was cut almost in half by the surtax.

\section{Conthued Growh of Sachgs Deposits}

The growth of business and individual deposits in financial institutions was somewhat slower in 1968 than the rapid pace of 1967 . The growth rates of time deposits at commercial banks and mutual savings banks, and of savings capital at savings and loan associations, continued to be relatively high on balance for 1968 , despite the sharp reduction in the proportion of income saved by individuals after mid-year.

Total time deposits at commercial banks consist of several distinct types of accounts, each subject to different interest rate ceilings, minimum amount requirements, and time to maturity restrictions. Therefore, growth of the various types of accounts is sometimes affected differently by changes in such economic conditions as personal and corporate income growth or yields avalable on competitive instruments.

One of the sharp distinctions among time deposit accounts is between negotiable certificates of deposit in excess of $\$ 100,000$ and other types of accounts. "Net time deposits" at commercial banks, a series consisting of total time deposits minus large negotiable certificates of deposit, are shown in the accompanying chart. Monthly data for the large certificates of deposit are shown in a separate chart.

Net time deposits are primarily passbook deposits and relatively small savings certificates. Passbook deposits are subject to a 4 per cent maximum interest rate limitation, and are usually payable on demand. Savings certificates are subject to a maximum interest rate limitation of 5 per cent per annum, but have a minimum size (generally $\$ 500$ or $\$ 1,000$ ), and usually are held for three months or longer.

Net time deposits grew at a relatively steady and rapid 12 per cent rate from 1962 to 1967 . From December 1967 to July 1968 the growth of these deposits slowed to a 7.4 per cent annual rate; then from July to November growth of these deposits accelerated to a 16 per cent rate. The slowing in the growth of net time deposits in early 1968 may be attributed to the relatively high and rising yields on other financial assets. Most interest rates reached

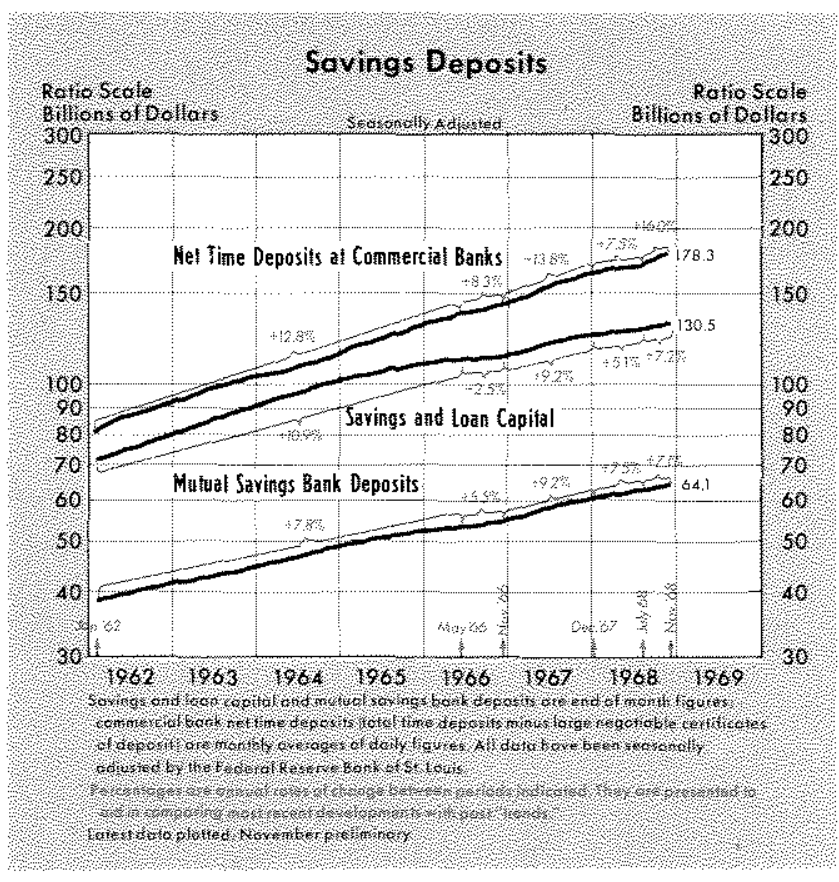

historic highs in May of 1968, before declining during the summer.

When market interest rates were rising in the first half of 1968 , the ability of banks to compete for time deposits was constrained by the maximum interest rates they were permitted to offer under Regulation $Q$ of the Federal Reserve System and corresponding regtlations of the Federal Deposit Insurance Corporation. As market interest rates declined in the summer, banks' competitive positions were improved and they were able to attract a substantial volume of time deposits.

On at least one previous occasion the ability of banks to compete for deposits had similarly been seriously hampered by regulated interest rate ceilings. This was during the summer and fall of 1966, commonly referred to as the "credit crunch" period. Most market interest rates rose sharply from early 1966 to September of that year, and then declined for the next six months. The maximum rates banks could pay on savings certificates had been raised from 4 per cent on maturities of $30-89$ days and $4^{1 / 2}$ per cent on others, to $5^{1 / 2}$ per cent on all savings certificates in December 1965. Thus commercial banks were able to offer competitive yields during the first part of the year. In July 1966 maximum bank rates on savings certificates were reduced to 4 per cent on maturities of 30-89 days and 5 per cent on longer maturities. Net time deposits rose at only an 8 per cent rate during the May-to-November "crunch," compared 
with a 12 per cent rate in the preceding six months and a 14 per cent rise in the following year.

Savings deposits at mutual savings banks have grown at a fairly stable 8 per cent annual rate since 1962. In early 1966 the growth of these deposits slowed substantially, while the growth of net time deposits at commercial banks continued to be fairly rapid due to raised Regulation $Q$ ceilings. From January to June of 1966 deposits at mutual savings banks increased at only a 3 per cent annual rate before accelerating to a 6.5 per cent growth rate for the remainder of the year. Then, from the end of 1966 through September of 1967, the growth rate of mutual savings bank deposits accelerated further, reaching over 10 per cent before sliding back to the 8 per cent trend rate.

Growth of savings capital at savings and loan associations showed a less stable trend from 1962 to 1968 than either net time deposits at commercial banks or deposits at mutual savings banks. From 1962 to 1965 savings and loan capital grew at a 12 per cent annual rate, about the same as the growth rate of net time deposits in that period.

In 1966 savings and loan associations were subject to pressures from both the demand for and the supply of funds. Market interest rates on other financial assets, such as three-month Treasury bills and commercial paper, were rising during most of the year, making it difficult to attract funds at relatively fixed dividend rates. Meanwhile, the demand for mortgage credit was falling as the demand for housing sagged. Savings capital at savings and loan associations increased only 3.3 per cent from December 1965 to December 1966, while net time deposits at commercial banks went up 10 per cent in the same period: Savings and loan associations were successful in attracting deposits at a rapid 11 per cent rate from January to September of 1967 , although growth of net time deposits continued at a somewhat higher 14 per cent rate throughout that year.

From September 1967 to June 1968 savings and loan capital increased at a relatively slow 5 per cent rate. From June to November 1968 the growth of savings and loan capital accelerated somewhat to a

\footnotetext{
In 1965 and throengh most of 1966 , savings and loan associations were subfect to de facto interest rate control by an amouncement that regional Home Loan Banks would restrict borrowing privileges of associations which declared at dividend rate higher than the rates of other associations in the area. In September 1966 savings and loan associations became subject to explicit interest rate control under the Stevens Act
}

7 per cent annual rate, in spite of the 10 per cent surtax on personal income and the decline in the proportion of take-home pay saved by households.

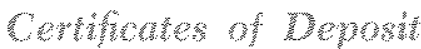

Commercial banks first began to issue large negotiable certificates of deposit (denominations of $\$ 100,000$ or more) in significant volume in 1961. By the beginning of 1962 the outstanding volume of CDs was about $\$ 3$ billion. Until mid-1963, the Federal Reserve System's Regulation $Q$ permitted member banks to pay only one per cent interest on CDs maturing in 89 days or less, $2^{1 / 2}$ per cent on maturities of 90 days to 6 months, $3 \frac{1}{2}$ per cent on maturities of 6 to 12 months, and 4 per cent on longer maturities. Maximum interest rates payable on CDs were raised in $1963,1964,1965,1966$ and 1968.

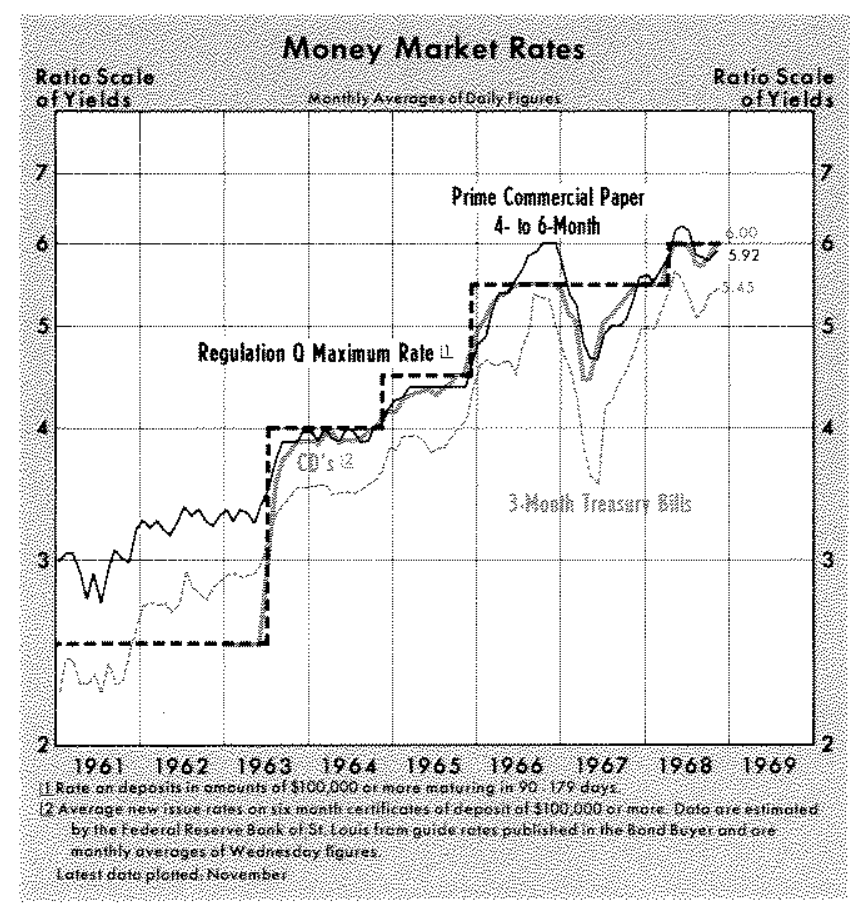

The new instrument proved to be efficient, and the outstanding volume of large negotiable certificates of deposit increased at about a 50 per cent annual rate from the beginning of 1962 to the end of 1965 . How ever, by the end of 1965 market interest rates had risen to such levels that the prevailing $4^{1 / 2}$ per cent ceiling rate on $\mathrm{CDs}^{3}$ made it difficult for banks to compete for funds. In December 1965 the Federal Reserve raised the ceiling rates on all maturities and denominations of time deposits to $51 / 2$ per cent (ceiling rates on passbook savings deposits were maintained at 4 per cent).

Fotr per cent on maturities of 30 to 89 days. 
The new issue rates on CDs rose rapidly in early 1966, accompanying generally rising market rates of interest. Since they were no longer effectively constrained by Regulation $Q$ ceiling rates, banks increased their outstanding volume of CDs until July of 1966, but at a much slower rate than in the previous four years.

Soon after the middle of 1966 , banks' offering rates on newly issued CDs had reached the $5 \frac{1 / 2}{2}$ per cent ceiling rates. Since yields on other market instruments continued to rise, banks were no longer able to compete effectively, and the volume of CDs outstanding declined sharply until the end of the year.

By December, most market yields had fallen sufficiently that banks were again able to increase their outstanding CDs. Yields on new issues of CDs fell a full percentage point from the end of 1966 to April 1967 before beginning to rise again. Banks increased their outstanding CD holdings 34 per cent during 1967. However, by December 1967 the yield on newly issued CDs had again risen to the $5^{1 / 2}$ per cent ceiling rate, accompanying the generally sharp increases in market rates of interest since the spring of that year.

As yields on competitive market instruments continued to rise in early $1968, \mathrm{CD}$ volume outstanding decreased over $\$ 2.4$ billion from December 1967 to June 1968. In mid-April the ceiling rates imposed under Regulation $Q$ were raised on large negotiable CDs maturing in 60 days or longer. The new cellings were graduated according to maturity from date of issue: $5^{1 / 2}$ per cent for 30 to 59 days, $5^{3 / 4}$ per cent for 60 to 89 days, 6 per cent for 90 to 179 days, and $6{ }^{1 / 4}$ per cent for 180 days or more.

Banks offering rates on CDs quickly rose to the new ceilings as most market interest rates were rising sharply last spring. However, in the summer shortterm yields declined and banks became competitive under the new ceiling rates. From June to November the outstanding volume of CDs increased about $\$ 5$ billion, or at a 76 per cent anmual rate, recovering the decline of $\$ 2.4$ billion in the first half of the year and leaving banks' holdings of CDs in November 14 per cent greater than a year earlier.

In November and early December of 1968 most short-term interest rates rose rapidly. By the end of November banks had raised offering rates on most maturities of CDs to the ceiling rates. Since banks were again becoming constrained in their ability to compete for funds, the outstanding volume of

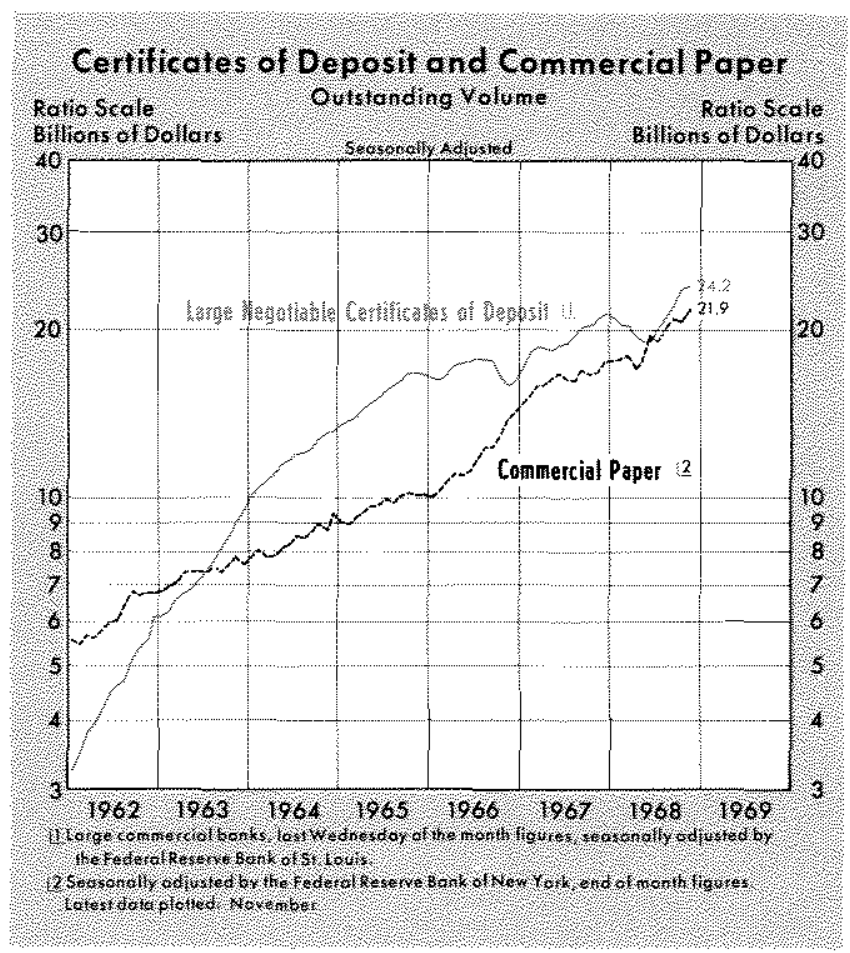

CDs increased only $\$ 446$ million from October to November.

\section{Comberan Panes}

Commercial paper is a financial instrument through which one business firm borrows short-term funds directly from another. Firms with a large amotnt of funds to lend for periods of a few months can choose among commercial paper, certificates of deposit, Treasury bills, or other marketable short-term instruments. Commercial paper and CDs are close substitutes from the point of view of the lending institution. Consequently, yields on CDs and commercial paper have generally shown similar patterns, with only a narrow spread between these rates. However, as discussed above, the rates banks can offer on newly issued CDs are at times constrained by Regu. lation $\mathrm{Q}$ ceilings, while sellers of commercial paper are not prevented from offering competitive yields.

The outstanding volume of commercial paper increased from the beginning of 1962 to the end of 1965 at a farly steady 16 per cent annual rate, much slower than the growth rate of CDs in the same period. In 1966, as banks' competitive abilities to issue CDs were hampered by the interest rate ceil4ncludes finance company paper as well as other commer-
cial paper placed directly and through dealers. 


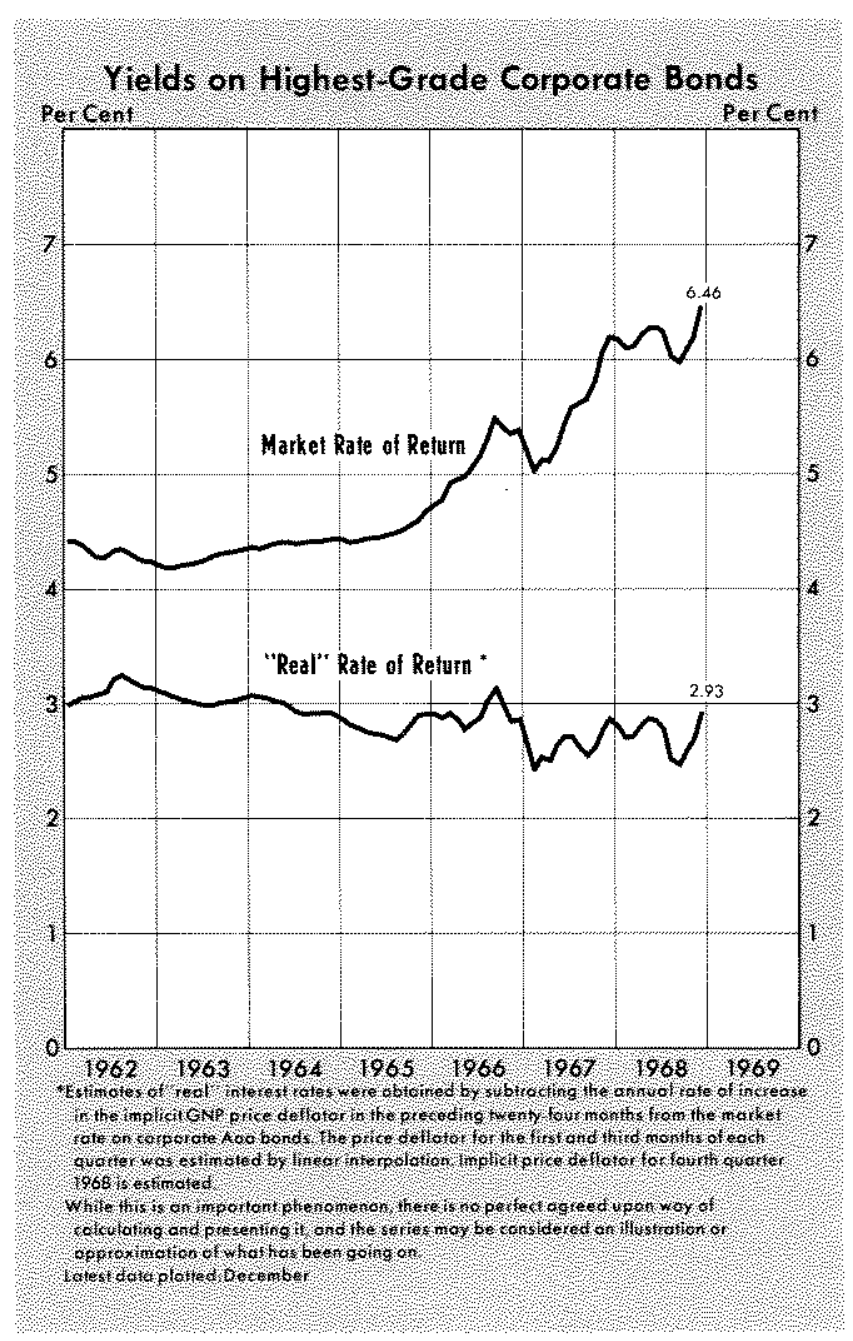

ings, commercial paper increased 46 per cent, while CDs declined on balance for the year.

As market rates of interest eased about the beginning of 1967 and banks' offering rates on CDs again became competitive, the rate of growth of outstanding commercial paper slowed, but continued at relatively rapid rates through June 1967 . From July 1967 until April 1968 the outstanding volume of commercial paper increased little on balance. Finally, from April to September commercial paper increased almost $\$ 4$ billion, or at over a 60 per cent annual rate. This sharp increase in commercial paper occurred despite the mid-year imposition of the 10 per cent surtax on corporate and personal incomes and the large increases in banks' $C D$ holdings after Jume.

\section{Stmmary and Outook}

Incomes of individuals continued to rise throughout 1968. However, when adjustments are made for higher taxes and rising costs of living, the improvem ment in individual well-being was substantially less than indicated by the growth of personal income. Nevertheless, saving as a proportion of disposable income in the last half of 1968 remained near the trend rate of the 1957 to 1967 period.

Changes in flows of saving into financial intermediaries in recent years have apparently depended more on the ability of these institutions to compete for funds in view of interest rate regulations than on changes in the total volume of saving. Intermution of normal channels of flows from saver to investor has probably reduced the efficiency of the financial system, and probably favors large borrowers who obtain funds in the capital markets relative to consumers, small businesses, and real estate buyers who rely more heavily on local financial institutions.

\section{Recent Monetary Developments}

In late 1968 market interest rates again reached levels which, in view of interest rate cellings, may constrain the ability of financial intermediaries to attract additional funds. The upward movement of market interest rates, which began in late summer, became sharper during December, as yields climbed above the high levels of last May. Interest rates on three-month Treasury bills averaged 5.95 per cent for the month, reaching an average weekly high of 6.20 per cent for the week ending December 27 compared with a 5.65 per cent average for May. Yields on highest grade corporate bonds averaged 6.46 per cent in December, compared with a previous high of 6.28 per cent.

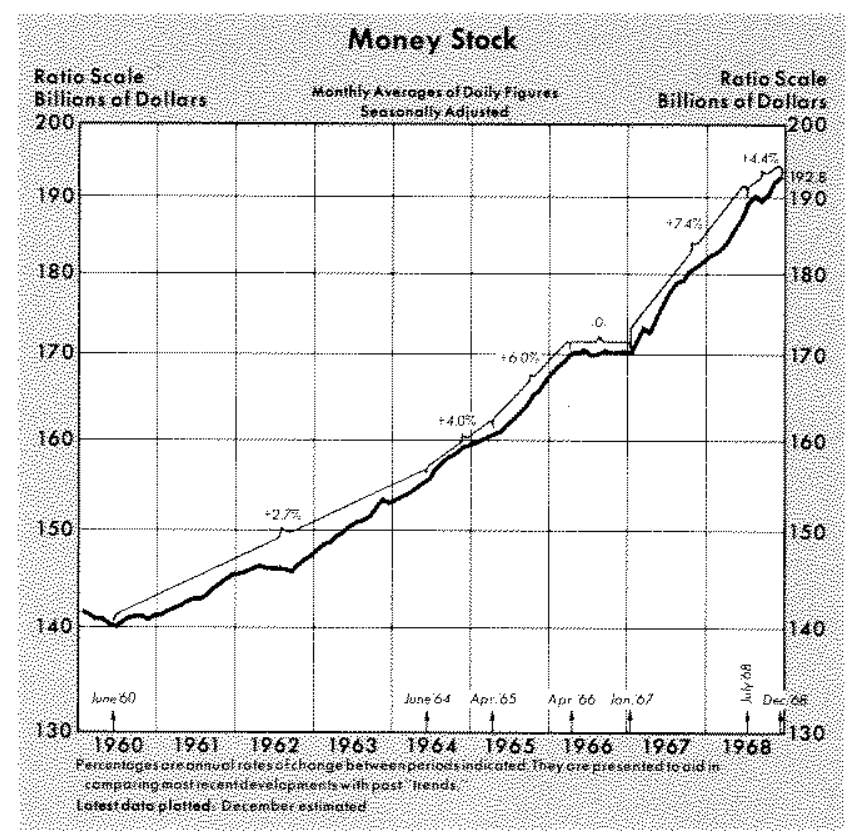




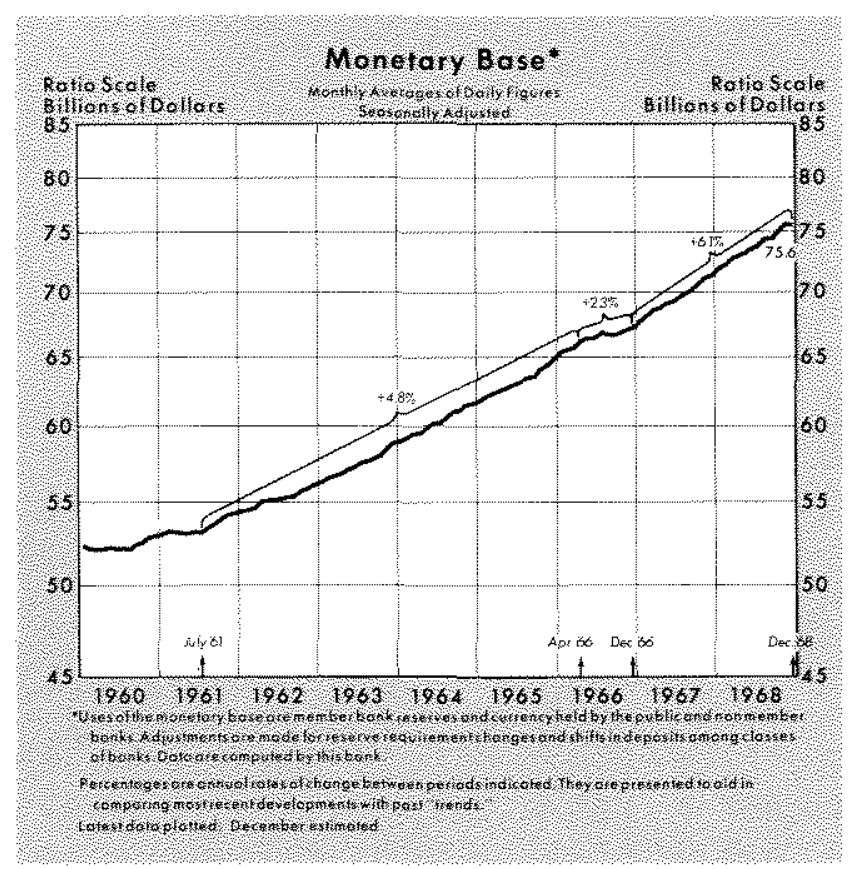

Expectations of continued rapid increases in spending and inflation, as well as heavy seasonal demands for credit, fostered the marked rise in interest rates. With growing expectations of continued inflation, interest rates typically go up, since lenders desire a greater nominal return in order to protect the purchasing power of funds, and borrowers expecting to repay their loans in cheaper dollars are willing to pay higher nominal interest rates.
Monetary expansion, as measured by the money stock, resumed a rapid pace in the fourth quarter. Money grew at a 7 per cent anmual rate from September to December and showed a similar 6 per cent increase for the entire year.

Growth of the monetary base, which largely determines the trend growth of the money stock, did not slow significantly during 1968 . The base advanced at a nearly steady 6 per cent annual rate from January to December, much faster than the 3.3 per cent average annual increase from 1957 to 1967. For the most part, the growth of the monetary base followed the rapid pace set by its largest source component, Federal Reserve credit, which increased 8 per cent during 1968.

The growth rates of other monetary aggregates, including the money stock plus time deposits and commercial bank credit, were at relatively high levels during 1968. The rapid monetary expansion, indicated by high growth rates of money, the monetary base, Federal Reserve credit, and bank credit, has not been successful in pushing down or preventing very high interest rates. It might be argued that increasing supplies of credit and money to meet the growing demand should tend to lower interest rates. This may be the case for very short periods. However, excessive monetary expansion may increase inllationary expectations, ultimately adding to upward pressure on interest rates.

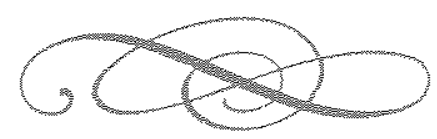

